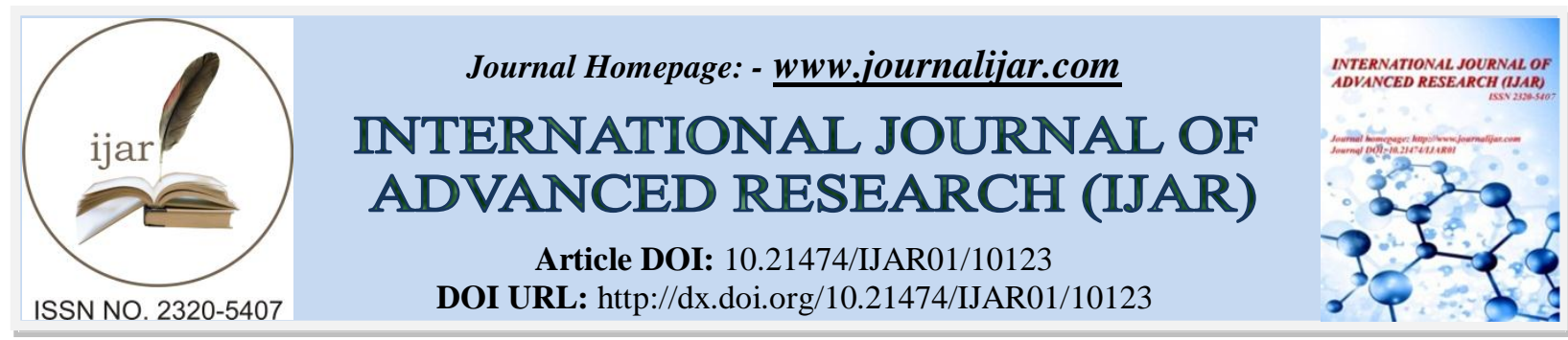

RESEARCH ARTICLE

\title{
COACHING OF SCHOOL IMPROVEMENT SPECIALIST COACHES PLUS (SISC+) AND TEACHERS' TEACHING COMPETENCY.
}

\section{Hareesol Khun-Inkeeree, Noorhazreen Sohri, Muhamad Suhaimi Muhammad, Mat Rahimi Yusof, Mohd Faiz Mohd Yaakob, M.S. Omar-Fauzee Dromarfauzee, Nurul Madera Ab Wahab and Fatimah Noor Rashidah Mohd Sofian.}

\section{Manuscript Info}

\section{Manuscript History}

Received: 01 October 2019

Final Accepted: 03 November 2019

Published: December 2019

\section{Key words:-}

School Improvement Specialist Coaches Plus, Teacher Teaching Competency, Teacher Quality, Knowledge and Interpersonal Skills.

\section{Abstract}

The rapid growth and change in education has forced teachers to find 'up to date' knowledge to improve their teaching pedagogy in the classroom. What's more, the latest development is to produce students who are capable of thinking at a high level thinking skills (HOTS). Therefore, teachers should need guidance in realizing Ministry of Education aspirations. Hence, this study was conducted to identify the influence of dimensions of knowledge and interpersonal skills within SISC + officer on improving teacher teaching competency. The method of the study was to use a quantitative method of questionnaire containing five points of likert scale. The instrument of the study was taken from a questionnaire developed by Pejabat Pendidikan Daerah Kluang (2015) for coaching of SISC + (16 questions). Whereas teacher teaching competency instrument (22 questions) is a questionnaire adapted from Spencer and Spencer (1992). A total of 186 teachers from six Jeli's district secondary schools were involved in the study. Data were analyzed using IBM SPSS version 25.0 to find mean values, standard deviations, Pearson correlations and Stepwise regression. The findings show that the level of SISC + coaching and teacher teaching competency are at a high moderate level. This shows that the teachers are accepting the SISC+ coaching program but with modification. Furthermore, the study shows that there is a positive but significantly weak relationship between SISC + coaching and teacher teaching competency. Therefore, SISC + officers need to continue to guide teachers to meet their needs as efficient instructors and follow the guidelines set for more positive relationship. Moreover, the regression statistic showed that SISC+ knowledge dimension do influences but only $6.3 \%$ towards teacher teaching competency, whereas interpersonal dimension was not significant. Further study by longitudinal study and interview should be conducted to find the causes of weak relationship and almost not influencing between SISC + coaching and teaching competencies (Knowledge and Interpersonal).

Copy Right, IJAR, 2019,. All rights reserved. 


\section{Introduction:-}

The world of education is constantly changing with the current developments and demands especially when education system will soon be embedded fully with the Industry revolution 4.0 policy (Shahroom \& Husin, 2018). All the policies and changes introduced require all educators to understand, appreciate, and apply them within their best (Kementerian Pendidikan Malaysia, 2012). This means that educators need to be more responsible in realizing the changes brought by the Ministry. This is because the teacher is the heart of the school and its professionalism is the key to produce quality performance as a teacher (Ibrahim, Yusof, Yaakob, \& Othman, 2019). The quality in this context involves not only the quality during the teaching and learning processed itself, but mostly it is also associated with the quality of the output (Saedah, 2012). This will not be possible if individuals, groups, and organizations are inefficient and ineffective in carrying out their responsibilities. To address the issue of inadequacy, changes need to be made by each teacher, especially in terms of the teacher's paradigm, attitude and behavior.

According to Nor Asiah (2017) the current changes implemented in the national school system require teachers who are knowledgeable and skilled in student-centered pedagogically in order to improve beneficial teaching and learning in the classroom.

These student-centered learning can assist teachers in transforming students' thinking patterns into 21 st century learning that is more challenging with the use of technology as learning takes place (Hasnah \& Jamaludin, 2017). It is also able to absorb high level thinking skills, use information technology and be able to communicate confidently inside and outside of the classroom (Puteri Faridah \& Umi Samra, 2018). With that method teachers will work effectively, be competitive and have high skills in teaching. Teachers should be aware that the concept of continuous improvement in the teaching profession coincides with the concept of the Malaysian Education Development Plan 2013-2015 that needs to be implemented continuously without a deadline to ensure that students are able to successfully cope with stress and challenges in the 21 st century. The implementation of the SISC+ to all district in Malaysia is to ensure the teachers being coached by the expert to conduct the student centered learning processes.

However, how the effectiveness of these teachers coaching program yet to be known in rural area, particularly in Jeli, Kelantan.

\section{Background:}

The twelve years period of Malaysian Education Development Plan (MEDP) 2013-2025 has clearly stated the challenges faced by teachers in implementing 21st century education to realize dynamic, futuristic, flexible and balanced student employment in all aspects (Kementerian Pendidikan Malaysia, 2012). In such circumstances, the role of teachers has become more complex, challenging and requires the commitment of teachers to support educational transformation so that it is relevant to the current environment (Suhaila \& Chua, 2019). Therefore, teachers have a great responsibility to produce high quality education because quality teaching process can only be achieved if the quality of teaching is exceptional (Nor Fariza \& Nur Fadhilah, 2018). However, according to the report of the Inspectorate of Schools (JNJK) in the MEDP report (Kementerian Pendidikan Malaysia, 2012), it is stated that only $13 \%$ of schools monitored are of excellent quality in teaching and learning and the rest are of good quality and hope. With less than $15 \%$ of schools in good standing, it shows that more effort is needed to improve teacher pedagogy so that they can impart knowledge and skills to pupils as envisaged in the 2013-2025 MEDP that lasted only six years. This is supported by the findings of Puteri Faridah and Umi Samra (2018) in which teachers need to be competent to combine resources and knowledge in order to educate their students in a balanced manner in line with the National Philosophy of Education.

The findings also indicate that there is still a high percentage and it is alarming that Malaysian teachers have not been able to meet the challenges of the 21 st century in realizing the aspirations of the Malaysian government and upholding the National Education Philosophy. The findings from the Inspectorate of Schools (JNJK) however, prove that the teaching competency of teachers in Malaysia is at an alarming rate (Kementerian Pendidikan Malaysia, 2012). In addition to the findings of a study conducted by the Academy of Higher Education - AKEPT (2011) which is reported in the Malaysian Education Development Plan 2013-2025 (Kementerian Pendidikan Malaysia, 2012), it was found that out of the 125 teachers teaching in 41 schools, only $12 \%$ of teaching is high standard who implemented pedagogical best practices while the remaining 38\% met satisfactory standards. It is even more surprising when $50 \%$ of teachers' teaching is unsatisfactory and does not meet the standards. This clearly indicates that teachers need to be regularly supervised by school management to ensure that teacher teaching standards are 
met (Dali, Daud, \& Fauzee, 2017). The findings show that Malaysian teachers have not been able to realize the ambitions of the Malaysian government and uphold the National Education Philosophy.

According to the report, the Ministry has strengthened the support system for teachers to enhance the delivery of teaching and learning. In addition to continuing to intensify regular supervision between teachers and school management, the Ministry of Education Malaysia has set up a new School Improvement Specialist Coaches Plus $(\mathrm{SISC}+)$ from the second initiative of the Continuing Professionalism Development Program (CPD) introduced under the Program District Transformation as a coach to train and guide teachers to be highly competent (KPM, 2012). This SISC + officer is responsible for providing systematic and systematic consultation to improve the quality of teacher teaching. They will be experts in the curriculum, assessment and pedagogical dimensions to guide, solve problems and develop good relationships with teachers professionally for school organization development (Leila, Zatul \& Siti, 2018). This is to identify the issues and problems faced by the school and to consider the interventions and improvements that can be taken to address the issues that arise. As a result, according to Nurul Syafinaz and Noraini (2018) the influence of the development of teacher professionalism on the improvement of teaching practice has shown significant improvement when teachers can improve their expertise in the content of teaching subjects and teaching strategies.

Face-to-face coaching can impact how teachers obtain information and improve their teaching practices and plan their professional learning (Salefah \& Norasmah, 2019). In addition, the coaching provided motivates the school community, facilitates the development of efforts by focusing on achievement, promoting the learning process of teachers in the context of work, encouraging them to reflect on the actions taken, involving all citizens at all levels. and foster a strong and flexible spirit to stay on track (Salwati, 2019). However, the SISC + coaching and mentoring program is not about boosting public exam results but more about teaching and learning for teachers to meet 21st century teaching and in line with National Education Policy that aims to produce students with high level thinking skills. Therefore, the purpose of this study is to examine how SISC + coaching program can enhance teacher teaching competency especially for rural secondary school teachers (Jeli District, Kelantan) in realizing MOE's desire to produce excellent students.

\section{Methodology:- Sampling:}

In this study, the respondents were comprised of all national high school teachers and Boarding School visited by SISC + officer in Jeli district, Kelantan. Researchers have used random sampling developed by Krejcie and Morgan (1970). Based on data obtained from the Jeli District Education Office, the population of teachers in six national high schools and SBPs was 357 (135 male; 222 female). Based on the sampling table of Krejie and Morgan (1970) the sample size is 357 therefore the appropriate sample size is 186 . If the population size is 357 , then the sample is 186 (65male; 121 female).

\section{Instrument of Study:}

The questionnaire is a measurement tool used to study the influence of SISC + coaching on school teacher teaching competencies. The questionnaire was divided into three sections, Part A covering demographics of respondents, Part $\mathrm{B}$ was to measure the level of guidance of SISC + using 16 original items from instruments developed by Pejabat Pendidikan Daerah Kluang, Johor. This instrument uses a 5-point Likert of 1) strongly disagree, 2) disagree, 3) neutral, 4) agree, and 5) Strongly agree. This instrument is to study the extent to which SISC + guidance can impact teacher change. Finally, the $\mathrm{C}$ instrument was to measure the level of teacher teaching competency using the questionnaire institution adapted from Spencer and Spencer (1992) questionnaire containing 22 items using fivescale (1) Never, 2) Once occasionally, 3) sometimes, 4) Quite often, and 5) Frequently. After conducting a field study, the researcher performed data analysis using IBM Statistical Package for The Science Social (SPSS) version 25.0 and was able to obtain the descriptive statistics and required inference. Both questionnaires had a high level of reliability with a cronbach's alpha greater than $.89 ; .80$. In a pilot study of 30 teachers at one of the schools in Jeli, Kelantan also found that this questionnaire had a high reliability of SISC +.96 ; while the reliability of the teacher teaching competency questionnaire had a Cronbach's alpha value of 0.94 .

\section{Study Procedures:}

Applications for the study have been applied through the Research and Policy Planning Division (EPRD) of the Ministry of Education Malaysia through UUM. Upon approval from the Ministry of Education Malaysia, it was forwarded to the Kelantan State Education Department and then to the Jeli District Education Office, Kelantan. With 
the approval of the Jeli District Education Office, a letter to collect data at the school was sent to the principal. Permission from school principals involved allowing researchers to perform data collection process when randomly selected teachers would answer the questionnaire that was self-administered by the researcher. The completed questionnaire will be personally collected by the researcher for analysis.

\section{Result:-}

Descriptive Test (Mean, SD):

Based on the analysis of SISC + guidance level data in the Jeli district as shown in table 2 it is shown that SISC + guidance practice is at a moderate level. For the analysis of data analysed the tables constructed by Nunnally and Bernstein (1994) were used as table 1 below.

Table 1:- The likert scale classification of the questionnaire items

\begin{tabular}{|c|c|}
\hline Mean Value & Level \\
\hline 1.00 to 2.00 & Very Low \\
\hline 2.01 to 3.00 & Low \\
\hline 3.01 to 4.00 & Moderate/High Moderate \\
\hline 4.01 to 5.00 & High \\
\hline
\end{tabular}

(Source: Nunnally \& Bernstein, 1994)

Table 2:- SISC+ Coaching Level in Jeli District

\begin{tabular}{|l|c|c|c|}
\hline & N & Mean & $\begin{array}{c}\text { Standard Deviation } \\
\text { (SD) }\end{array}$ \\
\hline SISC+ Coaching & 186 & 3.77 & .82 \\
\hline SISC+ Knowledge & 186 & 3.76 & .82 \\
\hline SISC+ Interpersonal Quality & 186 & 3.79 & .84 \\
\hline
\end{tabular}

Table 3:- Teachers Teaching Competency Level of Secondary School in Jeli District.

\begin{tabular}{|l|c|c|c|}
\hline & $\mathrm{N}$ & Mean & $\begin{array}{c}\text { Standard Deviation } \\
\text { (SD) }\end{array}$ \\
\hline Teacher teaching competency & 186 & 4.05 & .45 \\
\hline Teaching strategy, technique and method & 186 & 3.98 & .47 \\
\hline Communication with student & 186 & 4.12 & .49 \\
\hline Student reinforcement involvement & 186 & 4.07 & .48 \\
\hline
\end{tabular}

\section{Independent t-test and one-way ANOVA:}

Data analysis for teacher teaching competency level as shown in table 3 above shows that teacher competency for schools in Jeli district is high. The study also found that there was no significant difference in the independent sample t-test for teachers' (male and female) gender with teacher teaching competency. Meanwhile, one-way ANOVA results showed no significant differences between teachers' age and teacher teaching competency. Similarly, one-way ANOVA results between teachers' experience and teacher teaching competency showed no significant differences.

\section{Correlation test:}

Table 4:- Pearson Correlation Analysis of the Relationship Between SISC + Knowledge with Jeli's School Teacher Competency

\begin{tabular}{|l|l|c|c|}
\hline & & Teacher Competency & Knowledge \\
\hline Teacher competency & Correlation & 1 & $.251^{* *}$ \\
\hline & Sig(2-tailed) & & .001 \\
\hline & $\mathrm{N}$ & & 186 \\
\hline
\end{tabular}

** Correlation is sig. at a confidence level of 0.01 (2-tailed) 
Findings from the Pearson correlation test showed that the teaching ability of school teachers in the Jeli area had a weak and significant positive relation to the SISC + knowledge dimension with a correlation value of $\mathrm{r}=.251 * *, \mathrm{p}$ $=.001$.

Table 5:- Pearson Correlation Analysis of the Relationship Between SISC + Interpersonal Quality with School Teaching Competency in Jeli District

\begin{tabular}{|l|l|c|c|}
\hline & & Teacher Competency & $\begin{array}{c}\text { SISC+ Interpersonal } \\
\text { Quality }\end{array}$ \\
\hline Teacher Competency & Correlation & 1 & $.212^{* * *}$ \\
\hline & Sig(2-tailed) & & .004 \\
\hline & $\mathrm{N}$ & & 186 \\
\hline
\end{tabular}

** Correlation is sig. at a confidence level of 0.01 (2-tailed)

Findings from the Pearson correlation test showed that the teaching ability of school teachers in the Jeli district had a weak and significant positive relation to the SISC + interpersonal quality dimension with a correlation value of $\mathrm{r}=$ $.212 * *, \mathrm{p}=.004$.

Table 6:- Pearson Correlation Analysis of the Relationship Between SISC + Coaching with School Teacher Competency in Jeli District

\begin{tabular}{|l|l|c|c|}
\hline & & Teacher Competency & SISC+ Coaching \\
\hline Teacher Competency & Correlation & 1 & $.241 * *$ \\
\hline & Sig(2-tailed) & & .001 \\
\hline & $\mathrm{N}$ & & 186 \\
\hline
\end{tabular}

** Correlation is sig. at a confidence level of 0.01 (2-tailed)

Findings from the Pearson correlation test showed that the teaching competency of school teachers in the Jeli area had a weak and significant positive relationship with SISC+ coaching with a correlation value of $\mathrm{r}=.241 * *, \mathrm{p}=$ .001 .

Regression test:

Table 7:- ANOVA Results in Multiple Regression

\begin{tabular}{|c|l|c|c|c|c|c|}
\hline Model & & $\begin{array}{c}\text { Sum of } \\
\text { Squares }\end{array}$ & df & Mean Square & F & Sig. \\
\hline \multirow{2}{*}{1} & Regression & 2.391 & 1 & 2.391 & 12.391 & $.001^{\mathrm{b}}$ \\
& Residual & 35.592 & 184 & .193 & & \\
& Total & 37.983 & 185 & & & \\
\hline \multirow{2}{*}{2} & Regression & 1.713 & 1 & 1.713 & 8.689 & $.004^{\mathrm{c}}$ \\
& Residual & .891 & 48 & 0.19 & & \\
& Total & .991 & 50 & & & \\
\hline
\end{tabular}

1. The dependent variable: Teacher Competency

2. Predictors: (Constant), SISC+ Knowledge

3. Predictors: (Constant), SISC+ Interpersonal Quality

Based on Table 7, the test results show that for predicting teacher teaching competency model of regression there are two types of models where one model predicts SISC+ knowledge dimension of teacher teaching competency with $\mathrm{F}$ $=12.362, \mathrm{p}=.001^{\mathrm{b}}$. The two models predicted SISC+ interpersonal quality with teacher competency with $\mathrm{F}=8.689$, $\mathrm{p}=.004^{\mathrm{c}}$. Based on the regression test results it can be concluded that the SISC+ knowledge dimension is the most significant predictor of school teaching competency in Jeli district.

Table 8:-Results of Multiple Regression Analysis Using Stepwise Methods Over Teacher Teaching Competencies in Jeli Distric

\begin{tabular}{|c|c|c|c|c|c|c|c|c|c|c|}
\hline \multirow{2}{*}{$\begin{array}{l}\text { Mode } \\
1\end{array}$} & \multirow[t]{2}{*}{$\mathrm{R}$} & \multirow{2}{*}{$\begin{array}{c}\mathrm{R} \\
\text { Squar }\end{array}$} & \multirow{2}{*}{$\begin{array}{c}\text { Adjuste } \\
\text { d R }\end{array}$} & \multirow{2}{*}{$\begin{array}{c}\text { Std. } \\
\text { Error of }\end{array}$} & \multicolumn{5}{|c|}{ Change Statistics } & \multirow{2}{*}{$\begin{array}{c}\text { Durbin } \\
-\end{array}$} \\
\hline & & & & & $\mathrm{R}$ & $\mathrm{F}$ & $\mathrm{df}$ & $\mathrm{df} 2$ & Sig F & \\
\hline
\end{tabular}




\begin{tabular}{|l|c|c|c|c|c|c|c|c|c|c|}
\hline & & $\mathrm{e}$ & Square & $\begin{array}{c}\text { the } \\
\text { Estimat } \\
\mathrm{e}\end{array}$ & $\begin{array}{c}\text { Square } \\
\text { Chang } \\
\mathrm{e}\end{array}$ & $\begin{array}{c}\text { Chang } \\
\mathrm{e}\end{array}$ & 1 & & $\begin{array}{c}\text { Chang } \\
\mathrm{e}\end{array}$ & Watson \\
\hline 1 & $\begin{array}{r}.251 \\
\mathrm{a}\end{array}$ & .063 & .058 & .43981 & .063 & 12.362 & 1 & $\begin{array}{r}18 \\
4\end{array}$ & .001 & 1.755 \\
\hline
\end{tabular}

1. Predictors: (Constant), SISC+ Knowledge

2. Dependant variable: Teacher Competency

Based on table 8 shows that the most influential predictor of teacher teaching competency is SISC + knowledge of $\mathrm{r}=$ $.251 \mathrm{a}, \mathrm{r} 2=0.063, \mathrm{p}<.001$. Therefore, it can be concluded that SISC+ knowledge dimension slightly influences teacher teaching competency compared to SISC+ interpersonal quality dimension.

\section{Discussion:-}

Based on the findings of the study, it is found that the overall level of coaching of SISC + in Jeli schools is at a moderate level, whereas the two dimensions of SISC + (Interpersonal quality and knowledge) have showed that Interpersonal quality dimension mean score higher than knowledge dimension. This descriptive data shows that teachers are accepting the SISC+ programs (Nurul Syafinaz \& Noraini, 2018) conducted by the panel experts in the rural areas of Jeli, in the state of Kelantan, Malaysia. However, the result of descriptive data it still unable to answer how many percent of SISC+ coaching program did influenced the teacher competency. Nevertheless, it can therefore be said that SISC+ officers in the Jeli district practiced and were keen in building good relationships with teachers. The SISC+ officers seems maintaining their interpersonal quality so that the guidance provided can create a harmonious environment so that mentored teachers will strive to improve their teaching competencies and thus increase student engagement is as successful as it is. This is in line with the findings of Shamsudin (2016); and Nurul Syafinaz and Noraini (2018) who stated that collaboration between teachers and SISC+ officers can help improve the quality of teaching and learning in the classroom. Thus, it seems that the coaching of SISC+ strategy was different from the classroom supervision conducted by the head teacher which Che Khairuleffendi, Mohd Faiz and Hapini (2019) found that teachers' had the pessimistic mixed feelings especially during supervision. Apart from it, both SISC+ and class supervision by the head teacher should work together in order to help teachers to be more competence for teaching in the classroom. Moreover, it was found that the knowledge level of SISC+ coaches also need to be ensured that they are knowledgeable when mentoring the teachers. This is to help and open the minds of teachers to plan their teaching strategies and to apply the latest methods and techniques in teaching and learning of students to ascertain that student improvement in education is achieved. As Rozita, Rashid and Azhar (2016) pointed out, mentors play an important role in promoting knowledge development by sharing scientific writing materials to enhance existing knowledge and skills. This is aligned with the study by Noel Jimbal and Zamri (2017) who suggested that every SISC+ officer should have a high level of knowledge in providing guidance to their mentor to assist in improving teacher professionalism. Therefore, every SISC+ officers need to establish their knowledge in enhancing their coaching skill in producing excellent teachers. On the other hand, results for teachers' competency showed that communication with students dimension mean score is higher than student reinforcement involvement dimension and teaching strategy, technique and method dimension. This shows that the teachers perceived that good communication between teachers and students can produce teachers with good teaching competencies. Therefore, results also display that good guidance and supervision between SISC+ officers and teachers can produce excellent teachers to ensure quality student will be produced.

Based on the Pearson correlation data analysis, the study found a positive but weak significant relationship ( $\mathrm{r}=.241, \mathrm{p}$ $<.001$ ) between SISC+ coaching and teacher teaching competency in rural district of Jeli, in the state of Kelantan.

This suggests that SISC+ coaching is poorly related to teaching competency of secondary school teachers. It seems that the SISC+ coaching did not really accomplished in this rural area district. Perhaps, the interview should be conducted in order to understand why weak relationship between those two variables. Is it because of the poor coaching strategies, teachers themselves or the programs itself that make the relationship weak? However, previous research seems to recognize the SISC+ coaching program. It seems that highly knowledgeable SISC+ officers will make teachers more motivated to be excellent, innovative and creative teachers in the teaching and learning of the classroom (Sarabiah, 2018). Moreover, Nurul Syafinaz and Noraini (2018) stated that collaboration with SISC+ can enhance the quality of teaching and learning in the classroom. 
Apart from that, result also shows that the two dimensions of SISC+ (Knowledge dimension and Interpersonal quality dimension) have a weak positive relationship with teaching competency. Although the relationship between the two dimensions of knowledge and interpersonal skills are low, it still contributes to the improvement of teacher teaching competence. The two dimensions are intertwined with each other in which a SISC+ officer must be highly knowledgeable when guiding their coachee in order to assist and resolve any issues raised by their coachee (Sarabiah, 2018). In addition, interpersonal skills also need to be emphasized to ensure good relations can be established between SISC + and teachers so that guidance can be implemented harmoniously (Salefah \& Norasmah, 2019). Furthermore, it was also found that the SISC+ interpersonal skills dimension relationship $(r=.212, p=.004)$ was weaker than the relationship of knowledge dimension $(\mathrm{r}=.251, \mathrm{p}=.001)$. It is possible that the teachers in the Jeli district feel that the knowledge gained by SISC+ is quite important in guiding them to become competent teachers. This finding is in line with a study conducted by Nor Aisah (2017) who stated that SISC+ knowledge helps teachers to be more competent. Therefore, in order to create and produce competent teachers, SISC+ officers should play a key role in enhancing their knowledge in fulfilling the Ministry of Education's aspirations as stated in the Malaysian Education Development Plan (Kementerian Pendidikan Malaysia, 2012). The coaching of the SISC+ in guiding and implementing 21 st century learning is able to produce internationally competitive human being and produce outstanding students (Puteri Faridah \& Umi Samra, 2018).

Additionally, regression data analysis conducted using stepwise method yielded result which showed only knowledge dimension of SISC+ is significantly influence but with very low percentage (6.3\%) towards teaching competency of secondary school teachers in Jeli district, Kelantan. While the dimensions of SISC+ interpersonal quality did not significantly influenced. This finding means that SISC+ officers need to have a high level of knowledge to guide their teachers in order to become their idol. When teachers find that SISC+ officers are highly knowledgeable, they will trust these officers and feel that they are superior to them (Salafeh \& Norasmah, 2019).

Knowledgeable SISC+ officers are able to consult experts if they have concerns regarding their teaching in the classroom (Jimbal \& Zamri, 2017). Skills possessed by SISC+ for example pedagogical skills can influence teachers in the implementation of mentoring programs (Wong \& Abdullah, 2018). The effectiveness of the approach used by SISC+ can help teachers overcome problems or issues in teaching and learning through the mentoring process (Suhaili \& Chua, 2019). It can be concluded that SISC+ knowledge has a significant impact on teacher teaching competency in schools. However, in this case the SISC+ Jeli coaches' capability and capacity of mentoring the SISC+ mentoring program should be assessed further. Perhaps, the characteristic of teachers involved also need to evaluate by 'special audited unit' in order to understand the teachers behavior towards SISC+ program. Both of these suggestions were to ensure that the SISC+ will be sustainable as previous research believed that the program was beneficial to teachers (e.g., Salefah \& Norasmah, 2019; Suhaili \& Chu, 2019; Wong \& Abdullah, 2018).

On the other hand, an SISC+ officer also needs to be highly knowledgeable when coaching teachers especially in humanities and psychology. This is to build close relationships between SISC+ and their coachee so that the guidance process can be implemented harmoniously (Salefah \& Norasmah, 2019). Nor Aisah (2017) stated that SISC+ officers need to motivate mentored teachers to improve the quality of teaching in the classroom. SISC+ should know how to use teaching techniques that incorporate multiple intelligence and bring it to their coachee so that students can improve their intelligence where they can practice it when they are out of education. From the findings of previous studies, the skills of coaching have a great impact on the teaching style and the facilitation of teachers in producing quality teaching (Sarabiah, 2018; Jimbal \& Zamri, 2017). The role of SISC+ officers in influencing the changing patterns of teacher education in the classroom is crucial to ensuring that our country's education is at an all-time high and that student quality can be realized in line with the National Education Philosophy (Nor Aisah, 2017).

In addition, this study provides the impression that SISC+ officers need to have skills and knowledge in terms of assessment, pedagogy and curriculum (Jimbal \& Zamri, 2017). From the findings of Jimbal and Zamri (2017) SOSC+ officers should expect their teachers to be highly knowledgeable in order to improve their professionalism.

Therefore, a comprehensive and integrated effort must be taken by stakeholders to improve and enhance the coaching skills of SISC+ officers to be aligned with the needs of the 21st century education so that mentored teachers can implement classroom teaching in a sustainable manner needed by the Ministry of Education Malaysia (MOE, 2012). Perhaps, it is possible that a combination of teacher supervision with the SISC+ officers needs to be developed together to ensure greater success where teachers' competencies are consistently high. 
In examining the current educational phenomenon, the field of education today faces enormous challenges that require careful, systematic and holistic planning. Although SISC+ mentoring program in Jeli district has not yet shown a total impact, overall the SISC+ mentoring program can improve the quality of teaching and learning in the classroom and teachers' professionalism but its impact can still indicate that there are positive aspects even there are still in lower relationships (Wong \& Abdullah, 2018). Therefore, long-term qualitative and longitudinal studies need to be undertaken in this area to identify the relationship of SISC+ with teachers' competency (knowledge, interpersonal and teaching competencies). This finding does not seem to be consistent with the findings of Nor Asiah (2017); Salefah and Norasmah, (2019) who had identify that the role of SISC+ officers as teacher educators in implementing 21st century learning proves that the approach used by SISC+ officers has impacted the development of teacher professionalism to excellence level. The main focus of SISC+ coaching is to help improve teacher teaching competencies. It involves trying to change the behavior of teachers in the classroom. Teachers may find it difficult to get out of their comfort zone and change with the changing times. Likewise, students are not ready to inculcate a new millennium in a short time. So SISC+ officers play a role in guiding teachers out of the classroom and learning to interact with the ever-changing educational world.

\section{Conclusion:-}

In sum, the role of SISC+ coaching is not only to bring about changing in the classroom but also to change the culture and climate of the school. Improvements in instructional practices such as tolerance, respect and cooperation in problem solving can help teachers improve teaching and learning practices in the classroom (Sabariah, 2018). The role of school management in providing support to the SISC+ program and teacher supervision by school management needs to be integrated. It is therefore important that the collaboration between school management, teachers and SISC+ officers help to make climate change in the classroom before the results can be harvested. Professional development of teachers is an important aspect of ensuring success in the classroom. However, at the same time, SISC+ officers also need to be prepared and strengthen pedagogical knowledge as a supply for implementing guidance to mentored teachers (Wong \& Abdullah, 2018).

\section{Limitation of the study:}

This study is an attempt to identify the influence of SISC + coaching on teacher teaching competencies. However, researchers feel that this study is limited by several aspects. This study needs refinement and strengthening to achieve more comprehensive findings. The study is just a survey without putting together an interview and a longitudinal study to find out what really causes a weak relationship. The study is only conducted in the area of rural area of Jeli, in the State of Kelantan. Therefore, it is necessary to compare the findings with other cities to see what actually happens that contributing to the weak relationship between both dimensions. This study has the limitation of not seeing whether the teachers involved are really committed or forced to participate. Only teachers who are committed to ensuring the marketability of this SISC+ program should be reviewed to ensure that the program's sustainability is effective and secure.

\section{Reference:-}

1. Che Khairuleffendi Che Kamaruzaman, Mohd Faiz Mohd Yaakob, Hapini Awang. (2019). Tahap Dan Perasaan Ketika Penyeliaan Pengajaran Guru: Kajian Di Sekolah Agama Yayasan Islam Kelantan [Levels and Emotions During Supervising Teacher Teaching: A Review from Religious School of Kelantan Islamic Foundation]. Journal of Educational Research and Indigenous Studies [Jurnal Penyelidikan Pendidikan dan Pengajian Orang Asli], 2 (1), No page (article no. 20).

2. Coker, J.G., \& Coker, H. (1979, rev. 1982). Classroom observation keyed for effectiveness research: Obsever training manual. Carrollton, GA: Authors.

3. Hasnah Isnon \& Jamaluddin Badusah. (2017). Kompetensi guru Bahasa Melayu dalam menerapkan kemahiran berfikir aras tinggi dalam pengajaran dan pembelajaran [Malay languages's teacher competency in enforcing the higher order thinking in teaching and learning]. Jurnal Pendidikan Bahasa Melayu [Education journal in Malay Language], 7 (1), 56-66.

4. Ibrahim, M. Y., Yusof, M. R., Yaakob, M. F. M., \& Othman, Z. (2019). Communication skills : Top priority of teaching competency. 18(8), 17-30.

5. Kementerian Pendidikan Malaysia. (2012). Pelan Pembangunan Pendidikan Malaysia 2013-2025.[Malaysia Education Blueprint 2013-2025]. Putrajaya: Bahagian Pembangunan Kurikulum.

6. Kerjcie, R. V., \& Morgan, D. W. (1990). Determining sample size for research activities. Educational and Psychological Measurement, 3(3), 607-610. 
7. Leila Nasser, Nor Zaitul Shahira Zakaria \& Siti Nuraini Mukhtar. (2018). Pengaruh program intervensi dalam bimbingan dan pementoran berfokus oleh SISC+ impak terhadap kreadibiliti pengajaran guru di sekolah-sekolah Daerah Kinta Utara, Perak. [Effect of intervention programs on mentoring and mentoring focused by SISC + impact on teacher teaching credibility in North Kinta District schools, Perak] Prosiding Seminar Darulaman 2018 Peringkat Kebangsaan, [ National Proceeding Darulaman 2018] 191-196.

8. Noel Jimbal Balang \& Zamri Mahamod. (2017). Penerimaan guru-guru Bahasa Melayu terhadap bimbingan dan mentoran School Improvement Specialist Coach (SISC+) Daerah Selangau. [Acceptance of Malay teachers for guidance and mentoring of School Improvement Specialist Coach (SISC +) Selangau District] (Unpblished Masters Project Paper) Fakulti Pendidikan, Universiti Kebangsaan Malaysia.

9. Noel Jimbal Balang \& Zamri Mahamod. (2017). Penerimaan guru-guru Bahasa Melayu terhadap bimbingan dan pementoran SISC+ [Acceptance Malay Language Teachers on Guidance and Mentoring] Seminar Penyelidikan Pendidikan 1 [Educational Research Seminar] 280-291.

10. Nor Aisah Jamil. (2017). Pengukuran pembelajaran kemahiran berfikir aras tinggi dalam kalangan murid guru yang dibimbing (GDB) oleh pegawai SISC+[ Measurement of high-level thinking skills learning among student-led teachers (GDB) by SISC + officials]. Simposium Pendidikan diPeribadikan: Perspektif Risalah AnNur, 237-248.

11. Norfariza Mohd Radzi \& Nur Fadhilah Muzammil. (2018). Tahap kompetensi guru dalam pelaksanaan kemahiran berfikir aras tinggi di sekolah kebangsaan daerah Sepang, Selangor [ Levels of teacher competence in the implementation of high school thinking skills in Sepang, Selangor national school]. Jurnal Kurikulum dan Pengajaran Asia Pasifik [Asia Pacific Curriculum and Teaching Journal], 6(4), 12-28.

12. Nunnully, J.C. \& Bernstein, I.H. (1994). Psychometric theory, ( $3^{\text {rd }}$ edition). New York: McGraw-Hill

13. Nurul Syafinaz Ishak \& Noraini Ibrahim. (2018). Peranan SISC+ dalam pembudayaan Profesional Learning Community (PLC) di sekolah [The role of SISC + in the culture of Professional Learning Community (PLC) in schools] . Prosiding Seminar Darulaman 2018 Peringkat Kebangsaan [Proceedings of Darulaman 2018 National Level] 452-459.

14. Puteri Darishah Dali, Yaakob Daud \& Mohd Sofian Omar Fauzee. (2017). The relationship between teachers' quality in teaching and learning with students' satisfaction. International Journal of Academic Research in Business and Social Sciences, 7(7), 604-618.

15. Putri Faridah Hanizah Dahalan \& Umi Samra Md Saidan. (2018). Penglibatan SISC+ menerusi 'coaching \& mentoring' sebagai pemacu pembudayaan pendidikan abad ke 21 di SMK Kampung Bahagia [The involvement of SISC + through 'coaching \& mentoring' as the 21st century educational culture driver at SMK Kampung Bahagia]. Prosiding Seminar Darulaman 2018 Peringkat Kebangsaan [ Proceedings of Darulaman 2018 National Level], 158-165.

16. Rozita Radhiah Said, Abdul Rasid Jamian \& Azhar Md Sabil. (2016). Pengetahuan dan kefahaman skop pengajaran dan pembelajaran Bahasa Melayu dalam kalangan Jurulatih Pakar Pembangunan Sekolah (SISC+) [Knowledge and understanding of the scope of Malay language teaching and learning among School Development Specialists (SISC +)]. International Journal of Education and Training (InjET), 2(2), 1-9.

17. Salefah Mat Salleh \& Norasmah Othman. (2019). Assessment level implementation of School Improvement Specialist Coaches Program: Efficient teaching coaches features. International Journal of Academic Research in Progressive Education \& Development, 8(2), 142-158.

18. Salwati Shafee, Zuraidah Abdullah \& Simin Ghavifekr. (2019). Peranan amalan bimbingan dalam meningkatkan pembelajaran profesional guru [The role of mentoring practices in improving teacher professional learning]. Jurnal Kepimpinan Pendidikan [ Journal of Educational Leadership] 6 (1), 1-26.

19. Sarabiah Jusoh. (2016). Keberkesanan bimbingan SISC+ dari perspektif guru Bahasa Melayu [Effectiveness of SISC + guidance from the perspective of a Malay teacher]. (Unpublished Master Project). Fakulti Pendidikan, Universiti Kebangsaan Malaysia.

20. Sarabiah Jusoh. (2018). Persepsi, amalan dan keberkesanan bimbingan jurulatih SISC+ dari perspektif guru Bahasa Melayu [ Perceptions, practices and effectiveness of SISC + coach guidance from the Malay teacher perspective] . Jurnal Pendidikan Bahasa Melayu-JPBM [Journal of Malay Language Education] 8 (1), 42-52.

21. Saedah Siraj \& Mohammed Sani Ibrahim. (2012). Standard kompetensi guru Malaysia [Malaysian teacher competency standards]. Prosiding Seminar Kebangsaan Majlis Dekan Pendidikan IPTA 2012[Proceedings of the National Seminar on the Dean of Education 2012].

22. Shamsuddin Harun. (2016). Peranan coaching dalam revitalisasi pendidikan abad ke 21 [The role of coaching in the revitalization of 21st century education.]. Retrieved fromhttp://www.jprisma.com/v1/index.php/penulisan/8kepimpinan-dan-organisasi/43-peranan-coaching-dalam-revitalisasi-pendidikan-abad-ke-21 
23. Spencer, L.M. Jr., \& Spencer, S.M. (1993). Competence at work, models for superior performance. New York: John Wiley \& Sons, Inc.

24. Suhaili Jaya \& Chua Yan Piew. (2019). Tahap kompetensi dan hubungan bimbingan rakan peningkatan sekolah terhadap kompetensi kepimpinan sekolah di negeri Sarawak [Level of competence and relationship of school improvement partners to school leadership competencies in Sarawak.] . Jurnal Kepimpinan Pendidikan [Journal of Educational Leadership] 6(2), 16-43.

25. Wong Su Huong \& Nur Ain Elzira Abdullah. (2018). Bimbingan dan pementoran pembimbing pakar peningkatan sekolah (SISC+) menurut perspektif guru dibimbing (GDB)[ Guidance and mentoring of school improvement specialists (SISC +) in the perspective of a teacher-led (GDB)]. International Journal of Education, Psychology and Counseling, 3(13), 57- 72. 